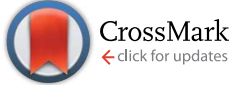

Cite this: RSC Adv., 2016, 6, 111031

\title{
SBA-15 mesoporous silica particles loaded with cisplatin induce senescence in B16F10 cells
}

\author{
David Edeler, ${ }^{\text {ab }}$ Milena R. Kaluđerović, ${ }^{c}$ Biljana Dojčinović, ${ }^{d}$ Harry Schmidt ${ }^{\mathrm{b}}$ \\ and Goran N. Kaluđerović*a
}

\begin{abstract}
The anticancer drug cisplatin (CP) is loaded into SBA-15 mesoporous silica (SBA-15|CP) and its release from the nanomaterial is studied. The CP-loaded SBA-15 is tested against four tumor cell lines: mouse malignant melanoma B16F10, human adenocarcinoma HeLa, colon HT-29 and prostate PC3. Most importantly, the superiority of this novel material in comparison to $\mathrm{CP}$ arises from the fact that the CP-grafted nanomaterial SBA-15 $(\rightarrow$ SBA-15|CP) is enhancing cessation of proliferation along with induction of senescence in B16F10 in approximately 3.5 times lower concentration. The control material loaded with therapeutically inactive $\mathrm{K}_{2}\left[\mathrm{PtCl}_{4}\right](\rightarrow \mathrm{SBA}-15 \mid \mathrm{TC})$ showed no antitumor activity. To a large extent, SBA15|CP-induced senescence might present a safe approach in tumor treatment. Such cells can be cleared by immune cells resulting in efficient tumor regression. So far only apoptotic agents are being exploited in clinics, thus an understanding of the chemotherapeutic-induced senescence will allow oncologists to explore this essential tumor suppressor mechanism.
\end{abstract}

Received 9th September 2016

DOI: $10.1039 / c 6 r a 22596 a$

www.rsc.org/advances (e.g. ruthenium(II/III), gold(III), tin(IV), titanium(Iv), etc.). ${ }^{8-13}$ Another is directed to development of chemical conjugation of $\mathrm{CP}$ using polymers. ${ }^{14,15}$ However, these strategies in general face similar problems as CP. Moreover in some cases even poorer water solubility is achieved for some potential drugs, which resulted in less therapeutic potentials. The polymer approach concerning coordination of polymer carboxylato groups to platinum(II) center showed to be unsuccessful for the desired controlled drug release at the target tumor sites. ${ }^{6}$

Alternative approach employing delivery systems through physical adsorption and trapping has been also explored. ${ }^{16}$ Even some attempts in the recent time were made, targeted delivery of CP to tumor cells without damaging healthy tissues and organs is very difficult, if not realizable with current technologies. ${ }^{17}$ The rationale of loading of highly active anticancer compounds into particles, as mentioned above, lies in the following: prevention of hydrolysis and accumulation in the healthy tissues/organs, tailorable drug release, as well as local application in tumor tissues in high doses. ${ }^{18,19}$ In last few years mesoporous silica materials are explored as carrier particles for various type of drugs (e.g. anti-inflammatory, anticancer drugs). ${ }^{20-22}$ Depending on the size of nanoparticles used they may be physiologically safe and exhibit no toxicity. ${ }^{23,24}$ This principle has already been explored through a number of works, therefore such nontoxic materials are suitable as drug carriers. ${ }^{25}$ Moreover, these materials reach malignant tissue quickly, thus lower concentration of medication efficiently affect tumor with less side effects. Typical nontoxic materials are structured mesoporous silica, such as MCM-41 (Mobil Composition of Matter 41), SBA-15 (Santa Barbara Amorphous 15) or TUD-1
${ }^{a}$ Department of Bioorganic Chemistry, Leibniz Institute of Plant Biochemistry, Weinberg 3, D 06120 Halle (Saale), Germany.E-mail: goran.kaluderovic@ipb-halle.de ${ }^{b}$ Institute of Chemistry, Martin Luther University Halle-Wittenberg, Kurt-MothesStraße 2, D-06120 Halle, Germany

${ }^{c}$ Department of Oral, Maxillary, Facial and Reconstructive Plastic Surgery, University Hospital of Leipzig, Liebigstr. 12, 04103 Leipzig, Germany

${ }^{d}$ Department of Chemistry, Institute of Chemistry, Technology and Metallurgy, University of Belgrade, Studentski trg 12-14, 11000 Belgrade, Serbia 
(Delft University of Technology 1). ${ }^{26}$ There are several reports in the literature on the mesoporous silica loaded with CP. However, mainly employing different mesoporous silica nanoparticle types or sizes, functionalization as well as codelivery with other drugs and or proteins. ${ }^{27-40}$ Beside investigations in drug delivery such materials are also applied as inert carriers for various other molecules (e.g. catalysts). ${ }^{\mathbf{4 1 , 4 2}}$

Pioneering investigations related to mesoporous silica loaded with metal complexes as potential anticancer delivery systems began in 2009. ${ }^{43}$ SBA-15 and MCM-41 loaded with titanium(Iv) and tin(IV) compounds have been investigated. ${ }^{43-47}$ SBA-15 was found to be superior to MCM-41 as carrier system, as well as organotin(Iv) over titanium(Iv) compounds. Thus, modified SBA-15 carrying organotin(Iv) compound $\mathrm{Ph}_{3}$ $\mathrm{Sn}\left(\mathrm{CH}_{2}\right)_{6} \mathrm{OH}$ was more than 150 times more active than SBA-15 loaded with the most effective titanium(Iv) complex. Strong therapeutic potential of organotin(Iv) loaded mesoporous silica lie in development of a nonproliferative melanocyte-like phenotype of surviving cells. Thus, this nonaggressive suppression of tumor growth with nontoxic doses of the drug is highly efficient against melanoma cells. Contrarily to the conventional approach in oncotherapy (induction of apoptosis), transformation of malignant phenotype into senescence and Schwann-like cells presents also non aggressive mode of drug action, all of them do not cause proliferative compensation.

The focus of this work is on the CP loaded SBA-15 $(\rightarrow$ SBA$15 \mid \mathrm{CP})$ as a simple delivery system with clinically used drug. Preparation, characterization and drug release studies are performed. The SBA-15|CP is tested against four tumor cell lines. On the most active B16F10 cell cycle perturbation, apoptosis, autophagy, ROS, proliferation potential and senescence induction upon treatment have been evaluated.

\section{Experimental section}

\subsection{Materials and methods}

$\mathrm{K}_{2}\left[\mathrm{PtCl}_{4}\right]$ (Merck), cisplatin (CP), pluronic 123 (P123) and TEOS (Sigma) were purchased and used as received from distributor.

\subsection{Characterization of the MSNs}

SEM and TEM imaging were performed on JEM-1010 (JEOL). EDX experiments were conducted on electron microscope JSM6701F and JSM-7500F (JEOL) as well as XL 30 ESEM-FEG (Philips). Sorptomatic 1900 Turbo Analysator (Carlo Erba Instruments) and NOVA 1000 (Quantachrome) were employed for nitrogen adsorption-desorption measurements. IR spectra were recorded on IR-Spectrometer Tensor 27 Platinum (Bruker) in the range $4000-200 \mathrm{~cm}^{-1}$. X-ray measurements (SAXS) were performed on a D8 ADVANCE (Bruker) X-ray diffraction system. ICP MS analysis was performed on Thermo Scientific iCAP Qc ICP-MS (Thermo Scientific, Bremen, Germany) spectrometer with operational software Qtegra.

\subsection{Preparation of SBA-15 (ref. 48)}

For the synthesis following materials were used: P123 (24.2 $\mathrm{g})$, water (180 mL), $\mathrm{HCl}(2 \mathrm{M}, 720 \mathrm{~g})$ and TEOS (51 g). Obtained material was heated $\left(1 \mathrm{~K} \mathrm{~min}^{-1}\right)$ to $500{ }^{\circ} \mathrm{C}$ and calcified for $24 \mathrm{~h}$. Yield: $15.6 \mathrm{~g}$; BET surface: $810 \mathrm{~m}^{2} \mathrm{~g}^{-1}$; pore volume: $0.83 \mathrm{~cm}^{3} \mathrm{~g}^{-1}$; pore diameter: $4.88 \mathrm{~nm}$; wall thickness: $4.39 \mathrm{~nm} ;{ }^{29} \mathrm{Si}$ MAS NMR (80 MHz, $\left.\delta\right):-108.9(\mathrm{~s}),-101.4(\mathrm{~s})$, -91.5 (s); IR: $\nu=1061$ (br, vs; Si-O-Si), 806 (w; Si-O-Si), 443 $\mathrm{cm}^{-1}$ (vs; Si-O-Si); XRD ( $2 \theta$ in ${ }^{\circ}$, Miller indices): 0.9512 (100), 1.6647 (111), 1.8956 (200); lattice parameter (nm): 9.3; crystal size (nm): 75.50.

\subsection{Preparation of SBA-15|TC and SBA-15|CP}

Grafting of SBA-15 was performed similarly to the procedure described in the literature. ${ }^{44,49}$ SBA-15 $(200 \mathrm{mg})$ was activated by drying under vacuum at $150{ }^{\circ} \mathrm{C}$ for $16 \mathrm{~h} . \mathrm{K}_{2}\left[\mathrm{PtCl}_{4}\right](83 \mathrm{mg})$ and cisplatin $(60 \mathrm{mg})$ respectively were suspended in toluene $(20 \mathrm{~mL})$. Obtained suspension was added to the activated SBA15 and the mixture was stirred at $80{ }^{\circ} \mathrm{C}$ for $48 \mathrm{~h}$. Afterwards reaction mixture was filtered and isolated material was washed successively with toluene $(2 \times 10 \mathrm{~mL})$ and $n$-pentane $(3 \times 10$ $\mathrm{mL}$ ). Obtained MSNs were dried under vacuum at room temperature.

SBA-15|TC. Yield: $279 \mathrm{mg}$; BET surface: $522 \mathrm{~m}^{2} \mathrm{~g}^{-1}$; pore volume: $0.55 \mathrm{~cm}^{3} \mathrm{~g}^{-1}$; pore diameter: $4.62 \mathrm{~nm}$; wall thickness: $4.64 \mathrm{~nm} ;{ }^{29} \mathrm{Si}$ MAS NMR (80 MHz, $\delta$ ): -110.0 (s), -101.6 (s), -91.6 (s); IR: $\nu=1061$ (br vs; Si-O-Si), 806 (w; Si-O-Si), 443 (vs; $\mathrm{Si}-\mathrm{O}-\mathrm{Si}$ ), $325 \mathrm{~cm}^{-1}$ (s, Pt-Cl); XRD ( $2 \theta$ in ${ }^{\circ}$, Miller indices): 0.9512 (100), 1.6647 (111), 1.8956 (200); lattice parameter (nm): 9.3; crystal size (nm): 77.54.

SBA-15|CP. Yield: $253 \mathrm{mg}$; BET surface: $561 \mathrm{~m}^{2} \mathrm{~g}^{-1}$; pore volume: $0.59 \mathrm{~cm}^{3} \mathrm{~g}^{-1}$; pore diameter: $4.41 \mathrm{~nm}$; wall thickness: $4.51 \mathrm{~nm} ;{ }^{29} \mathrm{Si}$ MAS NMR (80 MHz, $\delta$ ): -108.2 (s), -101.1 (s), -91.0 (s); IR: $\nu=1061$ (br, vs; Si-O-Si), 806 (w; Si-O-Si), 443 (vs; $\mathrm{Si}-\mathrm{O}-\mathrm{Si}$ ), $325 \mathrm{~cm}^{-1}$ (s, Pt-Cl); XRD ( $2 \theta$ in ${ }^{\circ}$, Miller indices): 1.0142 (100), 1.6962 (111), 1.9585 (200); lattice parameter (nm): 8.9; crystal size (nm): 75.26.

\subsection{Platinum release study}

After desorption of platinum(II) compounds from the SBA-15| TC and SBA-15|CP in purified water (sampling after time 0.08, $0.5,1,3,6,12,24$ and $48 \mathrm{~h}$ ), solid samples were analysed with EDX (no further sample preparation) while platinum content in liquid samples was investigated with ICP-MS. Explicitly, liquid samples were diluted with purified water $(1: 100, \mathrm{v} / \mathrm{v})$. The Thermo Scientific iCAP Qc ICP-MS instrument was optimized for optimum performance in He KED (kinetic energy discrimination) mode using the supplied autotune protocols. The ICP-MS instrument was tuned using a solution TUNE B iCAP Q $\left(1 \mu \mathrm{g} \mathrm{L}^{-1}\right.$ of each: $\left.\mathrm{Ba}, \mathrm{Bi}, \mathrm{Ce}, \mathrm{Co}, \mathrm{In}, \mathrm{Li}, \mathrm{U}\right)$ provided by the manufacturer Thermo Scientific, Germany. External Standards for the instrument calibration were prepared on the basis of a platinum plasma standard solution (Specpure ${ }^{\circledR}, \mathrm{Pt}$ $1000 \mu \mathrm{g} \mathrm{mL} \mathrm{m}^{-1}$ certified reference solution ICP Standard purchased from Alfa Aesar GmbH \& Co KG, Germany). For water extracts, the limit of quantitation (LOQ) for platinum was determined to be $46 \mathrm{ng} \mathrm{\textrm {L } ^ { - 1 }}$. The measurement was performed on isotope ${ }^{194} \mathrm{Pt}$. 


\subsection{In vitro studies}

CV, MTT, DAPI, CFSE (Sigma-Aldrich), RPMI-1640, phosphatebuffered saline (PBS), penicillin/streptomycin, 10× Dulbeccos PBS without $\mathrm{Ca}^{2+}$ and $\mathrm{Mg}^{2+}$, trypsin-EDTA 0.05\%/0.02\% (PAA

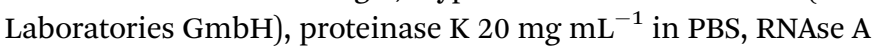
(Roche Diagnostics GmbH), DHR (VWR), annexin V/PI (BD Pharmagen), PI (BD Pharmagen), SA- $\beta$-Gal assay (Cell Signaling Technology) were used. B16F10 mouse skin melanoma and HT-29 colon adenocarcinoma cells were kindly obtained from Prof. B. Seliger (Martin Luther University Halle-Wittenberg, Germany), while HeLa human cervix adenocarcinoma cells from Ontochem (Halle, Germany). PC3 human refractory prostate cancer cells was purchased from the German Collection of Microorganisms and Cell Cultures (DSMZ, Germany). Tumor cell lines B16F10, HeLa, HT-29 and PC3 were routinely maintained in RPMI-1640 medium supplemented with 10\% FCS and 1\% antibiotics (culture medium) at $37{ }^{\circ} \mathrm{C}$ in a humidified atmosphere with $5 \% \mathrm{CO}_{2}$. Stock solutions of platinum(II) complexes $(20 \mathrm{mM})$ and MSNs $\left(20 \mathrm{mg} \mathrm{mL}^{-1}\right)$ were freshly prepared in DMSO or in PBS, respectively, and diluted to various working concentrations with medium. Microphotographs were obtained using a fluorescence microscope (Carl Zeiss). Flow cytometry was performed on BD FACS Aria III and analyzed using BD FACSDiva software (BD Biosciences, Heidelberg, Germany).

\subsection{CV and MTT assays}

The viability of the cells was measured by CV and MTT assays as described previously. ${ }^{50}$ Absorbance was measured using a 96well plate reader (Tecan Spectra, Crailsheim, Germany). $\mathrm{IC}_{50}$ $[\mu \mathrm{M}]$ and $\mathrm{MC}_{50}\left[\mu \mathrm{g} \mathrm{mL}{ }^{-1}\right]$ values, defined as the concentration of the compounds at which $50 \%$ of cell inhibition occur were calculated using four-parameter logistic function and presented as mean from three independent experiments.

\subsection{Cell cycle analysis}

In the 6 well plate $1 \times 10^{5} \mathrm{~B} 16 \mathrm{~F} 10$ cells per well were incubated with $\mathrm{IC}_{50}, 2 \times \mathrm{IC}_{50}$ or $\mathrm{MC}_{50}, 2 \times \mathrm{MC}_{50}$ doses of CP and SBA$15 \mid \mathrm{CP}$ for 24 and $48 \mathrm{~h}$ and cell cycle analysis was performed using DAPI stain.

\subsection{Apoptosis detection}

In the 6 well plate $1 \times 10^{5} \mathrm{~B} 16 \mathrm{~F} 10$ cells per well were incubated with $\mathrm{IC}_{50}, 2 \times \mathrm{IC}_{50}$ or $\mathrm{MC}_{50}, 2 \times \mathrm{MC}_{50}$ doses of $\mathrm{CP}$ and SBA-15|CP for 24 and $48 \mathrm{~h}$. Afterwards, annexin V/PI protocol was applied as described in the literature. ${ }^{51}$

\subsection{Morphological analysis (AO staining)}

A staining of the B16F10 cells with AO (Sigma-Aldrich), according to standard procedures, ${ }^{52}$ was used for this purpose. B16F10 cells were seeded overnight on 4 chamber slide $\left(1 \times 10^{4}\right.$ cells per chamber $)$ in $500 \mu \mathrm{L}$ of complete medium. The next day, cells were treated with $2 \times \mathrm{IC}_{50}$ and $2 \times \mathrm{MC}_{50}$ doses of $\mathrm{CP}$ and SBA-15|CP, respectively for $24 \mathrm{~h}$. Afterwards, cells on the slides were stained with $\mathrm{AO}\left(3 \mu \mathrm{g} \mathrm{mL}^{-1} \mathrm{AO}\right.$ in PBS), and visualized under a fluorescence microscope (Carl Zeiss).

\subsection{DHR and CFSE staining}

At first cells were stained with DHR or CFSE analogously as described in the literature. ${ }^{53,54}$ B16F10 cells were seeded in the 6 well plate at density of $1 \times 10^{5}$ cells per well. After $24 \mathrm{~h}$ cells were incubated with $\mathrm{IC}_{50}, 2 \times \mathrm{IC}_{50}$ or $\mathrm{MC}_{50}, 2 \times \mathrm{MC}_{50}$ doses of CP and SBA-15|CP. Flow cytometry was performed for DHR and CFSE assay after for 48 and $72 \mathrm{~h}$ of treatment, respectively.

\subsection{Senescence (SA- $\beta$-gal) assay}

B16F10 cells were seeded overnight on 4 chamber slides (10 000 cells per chamber) in $500 \mu \mathrm{L}$ of complete medium. The next day, cells were treated with $\mathrm{IC}_{50}$ and $\mathrm{MC}_{50}$ doses of $\mathrm{CP}$ and SBA-15|CP, respectively for $48 \mathrm{~h}$. The medium was removed and cells were washed in PBS, fixed and stained with a $\beta$ galactosidase reagent. Chamber slides were incubated over night at $37{ }^{\circ} \mathrm{C}$ without $\mathrm{CO}_{2}$ and then observed in bright and fluorescence field under a fluorescence microscope (Carl Zeiss).

\section{Results and discussion}

\subsection{Preparation of mesoporous silica materials}

The selection of CP was firstly due to the known biological potential. ${ }^{55}$ Moreover, inspired with previous results on SBA-15 derivative loaded with $\mathrm{Ph}_{3} \mathrm{Sn}\left(\mathrm{CH}_{2}\right)_{6} \mathrm{OH},{ }^{44}$ it is of interest to investigate if the antitumor activity of $\mathrm{CP}$ can be improved by using SBA-15 carrier particles. Also, $\mathrm{K}_{2}\left[\mathrm{PtCl}_{4}\right]$ (TC) as antitumor inactive platinum(II) complex grafted into SBA-15 $(\rightarrow$ SBA-15|TC), was parallel used for desorption and in vitro studies. Preparation of SBA-15 was performed according to the literature procedures. ${ }^{56}$ SBA-15|TC and SBA-15|CP were prepared by loading of TC and CP, respectively, into SBA-15. The SBA-15|TC and SBA-15|CP nanomaterials, as well as SBA-15, have been extensively characterized. For detection and quantification of platinum in SBA-15|TC and SBA-15|CP particles EDX analysis was performed. The evaluation showed that loading of the platinum(II) complexes TC and CP in SBA-15 occurred successfully (SBA-15|TC: $2.0 \mathrm{wt} \% \mathrm{Pt}$; SBA-15|CP: $12.1 \mathrm{wt} \% \mathrm{Pt}$ ). SEM and TEM analyses were used to investigate whether a change or damage of starting SBA-15 had occurred upon loading of platinum(II) complexes (Fig. 1). A uniform morphology with hexagonal distribution of rod-shaped MSNs (mesoporous silica nanoparticles, herein: SBA-15, SBA-15|TC and SBA-15|CP) was observed by SEM and TEM analyses. The dimensions of nanomaterials before and after the loading are with narrow size distribution (approximately 200-400 $\times 600-$ $800 \mathrm{~nm}$ ). The physical parameters of nitrogen adsorptiondesorption isotherms, BET surface area, average pore diameter, average pore volume, and wall thickness for the three MSNs were measured.

The mesoporous nature of nanomaterials was confirmed by nitrogen adsorption-desorption analysis, thus type IV isotherms ${ }^{57}$ were observed for all materials (Fig. 2A). The hysteresis loop generally appeared between the adsorption and desorption branches, which indicates the capillary condensation of porous structure. In all cases, the capillary condensation of nitrogen started at $p / p_{0}=0$ and extended up to 1 , proving the 


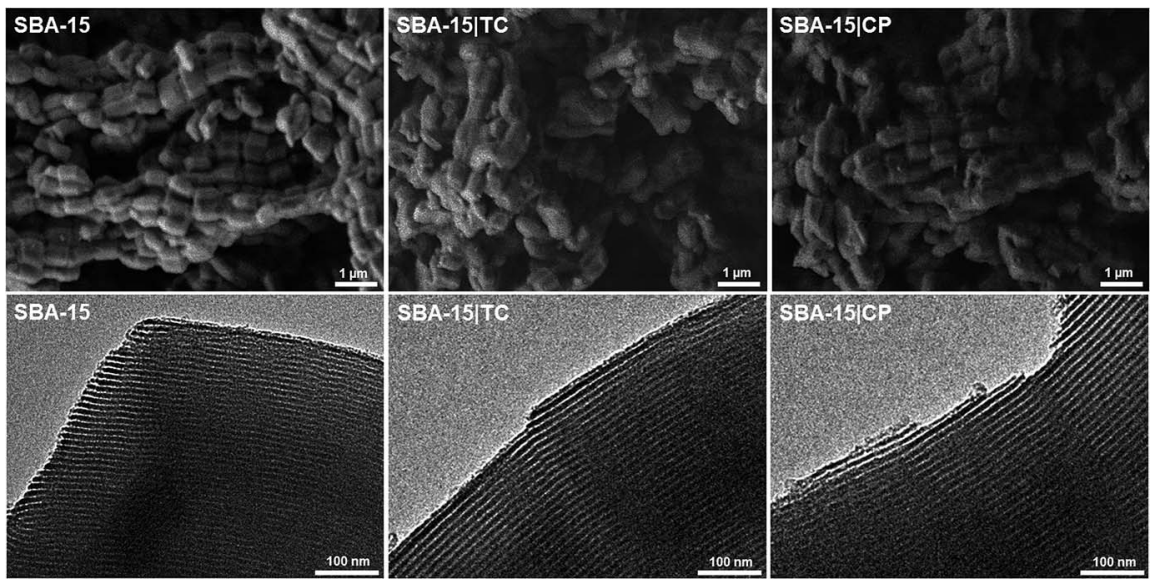

Fig. 1 SEM (upper) and TEM images (lower) of MSNs: SBA-15, SBA-15|TC and SBA-15|CP.
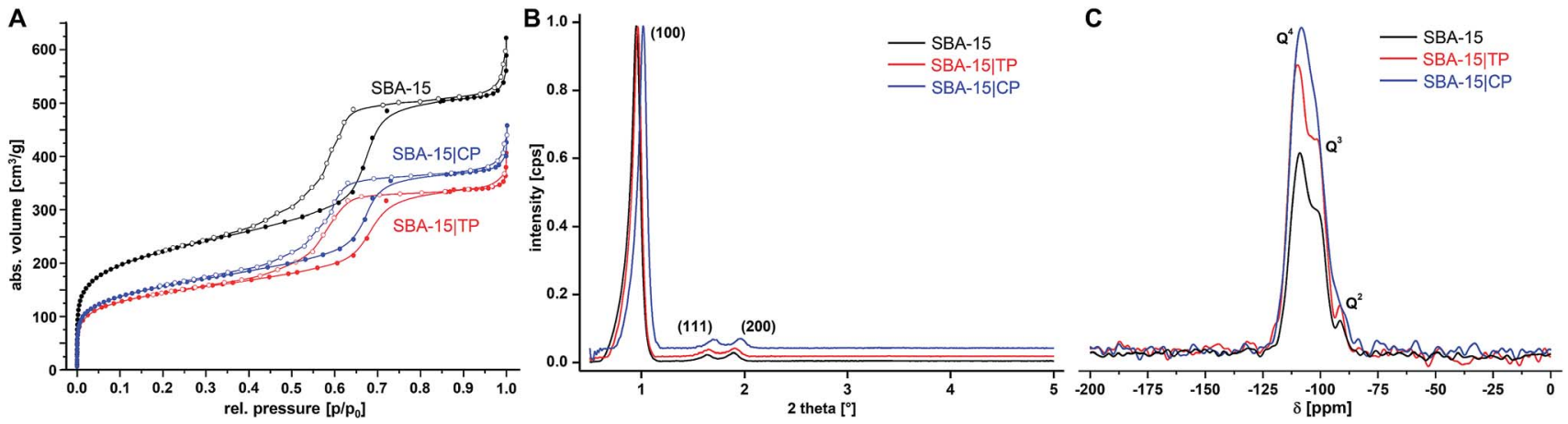

Fig. 2 (A) $\mathrm{N}_{2}$ adsorption-desorption isotherms; (B) SAXS patterns and (C) ${ }^{29} \mathrm{Si}$ MAS NMR spectra of MSNs.

wide pore distribution in the synthesized MSNs. The pore diameter as well as surface area of MSNs decreased upon loading with platinum(II) complexes (Table 1). This can clearly be seen by the decrease of absolute absorbed volume of nitrogen in MSNs (Fig. 2A).

Uniform pore diameter of 4.88 (SBA-15), 4.62 (SBA-15|TC) and $4.41 \mathrm{~nm}$ (SBA-15|CP) was determined. A high BET surface of 810,522 and $561 \mathrm{~m}^{2} \mathrm{~g}^{-1}\left(S_{\mathrm{BET}}\right)$ for SBA-15, SBA-15|TC and SBA$15 \mid \mathrm{CP}$, respectively, were noticed. In combination with smallangle X-ray scattering experiments (SAXS) wall thickness was determined: $4.64 \mathrm{~nm}$ SBA-15|TC, $4.51 \mathrm{~nm}$ SBA-15|CP (increased in comparison to SBA-15: $4.39 \mathrm{~nm}$ ). In addition to wall thicknesses lattice parameters and crystallite sizes are also defined. For all materials similar values for the lattice parameter could be detected. This was expected since this parameter specifies the repetition rate of the hexagonal pores of the MSNs. The crystallite size (calculated by the Debye-Scherrer equation) determined for all nanomaterials is almost identical. From the slight variations of this parameter can be concluded that the particles are structurally unchanged. Consequently, it can be confirmed that TC or CP loading of SBA-15 did not have any influence on the structure.

The X-ray reflections from the unit cell can be assigned to the $\alpha$-quartz, trigonal, P32. A well-resolved pattern at low $2 \theta$ values with a very sharp (100) diffraction peak was observed for all three MSNs (Table 1 and Fig. 2B). X-ray diffraction pattern (XRD) of the MSNs displayed reflections typical for hexagonally ordered mesoporous materials. ${ }^{47}$ In the ${ }^{29}$ Si MAS NMR spectra of all materials typical resonances at $-91.5,-101.4$ and $-108.9 \mathrm{ppm}$ assigned to $\left[\mathrm{Si}(\mathrm{OSi})_{2}(\mathrm{OH})_{2}\right](\mathrm{Q} 2),\left[\mathrm{Si}(\mathrm{OSi})_{3}(\mathrm{OH})\right](\mathrm{Q} 3)$ and $\left[\mathrm{Si}(\mathrm{OSi})_{4}\right](\mathrm{Q} 4),{ }^{43}$ respectively, were observed (Fig. 2C).

From the IR spectra of MSNs asymmetrical stretching vibrations of Si-O-Si are found at around $1060 \mathrm{~cm}^{-1} .^{58}$ These absorptions correspond to the silicon framework. Symmetrical stretching vibrations of $\mathrm{Si}-\mathrm{O}-\mathrm{Si}$ (ring structures) are found at around $806 \mathrm{~cm}^{-1}$, while corresponding bending vibrations are located at around $443 \mathrm{~cm}^{-1}$. Additionally, in the IR spectra of SBA-15|TC and SBA-15|CP bands at $325 \mathrm{~cm}^{-1}$ originate from $\mathrm{Pt}-\mathrm{Cl}$ stretching vibrations.

\subsection{Release of CP from the SBA-15|CP particles}

To obtain a first insight into the desorption behavior of the platinum(II) compounds, TC and CP, from SBA-15|TC and SBA-15|CP drug release studies were conducted. To simplify system these investigations were carried out in purified water. The SBA-15|TC and SBA-15|CP materials were soaked in purified water and after $0.08,0.5,1,3,6,12,24$ and $48 \mathrm{~h}$ assayed for their metal contents by means of EDX and ICP-MS. The results of these studies are summarized in Fig. 3. 
Table 1 Selected physical parameters of the MSNs used

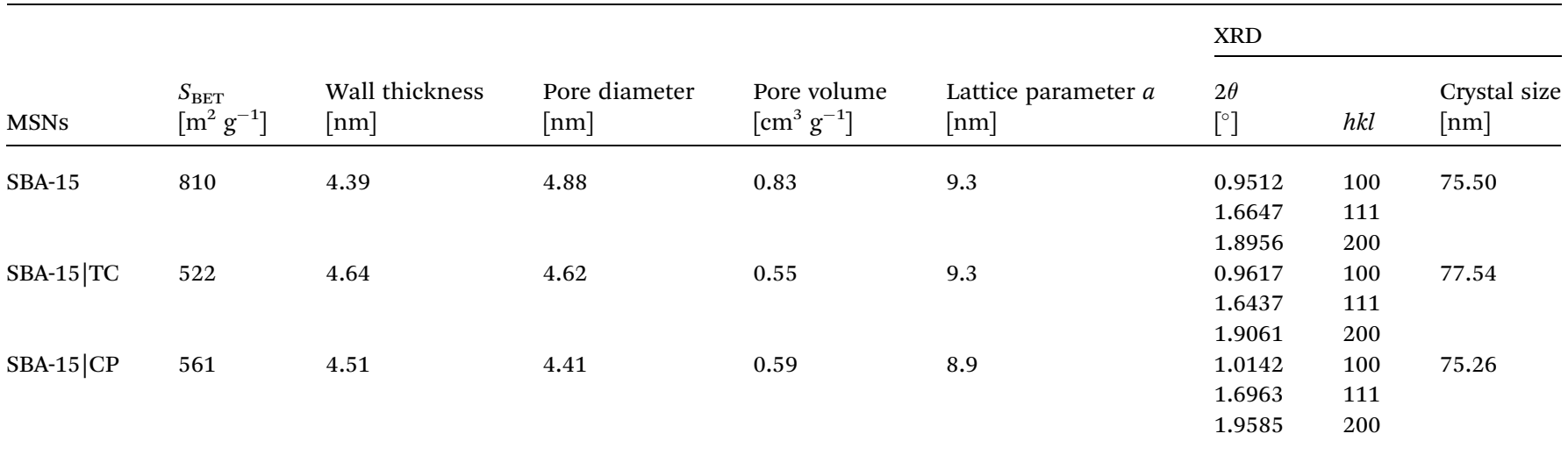

The evaluation of TC and CP desorption from SBA-15|TC and SBA-15 $\mid \mathrm{CP}$, respectively, shows that the nanomaterials behave quite similar (Fig. 3, left). After short time chlorine, potassium or platinum could not be detected by EDX in loaded SBA-15. The contents of these elements could be determined only at below 0.1 at $\%$ from $0.5 \mathrm{~h}$ desorption time (absolute error of \pm 0.1 at $\%)$. The findings are in agreement with literature observations. ${ }^{28}$ Due to the high solubility of the platinum(II) complexes it was not possible to detect locally increased concentrations on the surface of the carrier material. In concordance to EDX, ICP-MS showed increased concentration of platinum compounds in desorption medium (Fig. 3, right).

\subsection{Cytotoxicity of SBA-15|CP particles}

The in vitro anticancer activity of platinum(II) complexes (TC and CP) as well as MSNs (SBA-15, SBA-15|TC and SBA-15|CP) was assessed against four different tumor cell lines: mouse malignant melanoma B16F10, human adenocarcinoma HeLa, colon HT-29 and prostate PC3. CV and MTT assays were used for investigations upon $48 \mathrm{~h}$ of treatment with investigated compounds and MSNs (Fig. 4). Furthermore, cytotoxicity of SBA-15 against same tumor cell lines was determined. The $\mathrm{IC}_{50}$ and $\mathrm{MC}_{50}$ values are reported in Tables 2 and 3 .
The CV and MTT results are in good agreement with except of CP and SBA-15|CP against HT-29 cell line. Thus, in that case respiration of the HT-29 cells are affected with both CP and SBA-15|CP. However, this effect is slightly more enhanced with SBA-15|CP. As shown previously SBA-15 was found to be inactive $\left(>100 \mu \mathrm{g} \mathrm{mL}^{-1}\right)$ against tumor cell lines. ${ }^{44}$

Furthermore, TC was ineffective against all investigated tumor cell lines $(>100 \mu \mathrm{M})$. Expectedly, SBA-15|TC did not show any activity too $\left(>100 \mu \mathrm{g} \mathrm{mL}{ }^{-1}\right)$. The most effective agents were found to be CP and SBA-15|CP against B16F10 cell line. The activity of SBA-15|CP is ca. 300 times higher than that of the most active SBA-15 loaded with titanocene compound [Ti $\left.\left\{\mathrm{Me}_{2} \mathrm{Si}\left(\eta^{5}-\mathrm{C}_{5} \mathrm{Me}_{4}\right)\left(\eta^{5}-\mathrm{C}_{5} \mathrm{H}_{4}\right)\right\} \mathrm{Cl}_{2}\right]\left(\mathrm{MC}_{50}=309 \pm 42 \mu \mathrm{g} \mathrm{mL}{ }^{-1}\right){ }^{43}$ and its activity is twice as high as functionalized SBA-15 derivative with tetraorganotin(Iv) compound $\left(2 \mu \mathrm{g} \mathrm{mL}^{-1}\right.$; $\left.\mathrm{Ph}_{3} \mathrm{Sn}\left(\mathrm{CH}_{2}\right)_{6} \mathrm{OH}\right){ }^{44}$

Slightly higher or similar activity of SBA-15|CP in comparison to CP against HT-29 as well as HeLa and PC3 cells lines, respectively, was found. Most importantly, taking into consideration a low platinum content in SBA-15|CP (12.1 wt\%) the effectiveness of the lower concentration of $\mathrm{CP}$ in mentioned material is 3.5 times higher against B16F10 than the activity of $\mathrm{CP}$ alone. In respect to this, when applied in vivo SBA-15|CP presumably will cause fewer side effects than CP due to its lower concentration.
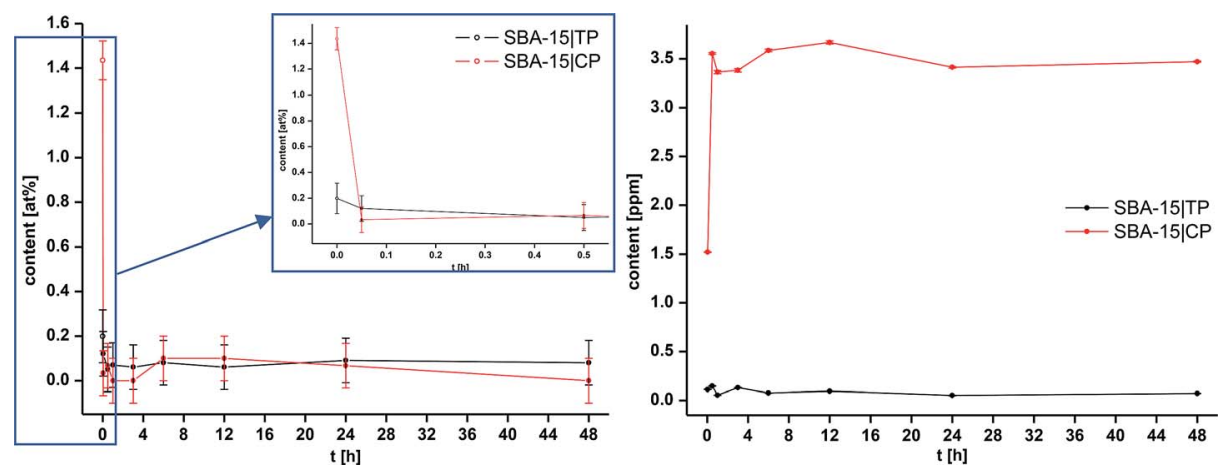

Fig. 3 Release study of platinum(॥) complexes from the SBA-15|TC and SBA-15|CP, remaining Pt content of carrier material (left, EDX analysis), found Pt content in solution (right, ICP-MS analysis). For comparison, the metal contents of unsoaked dry nanomaterials are shown as well (left: $0 \mathrm{~h})$. 

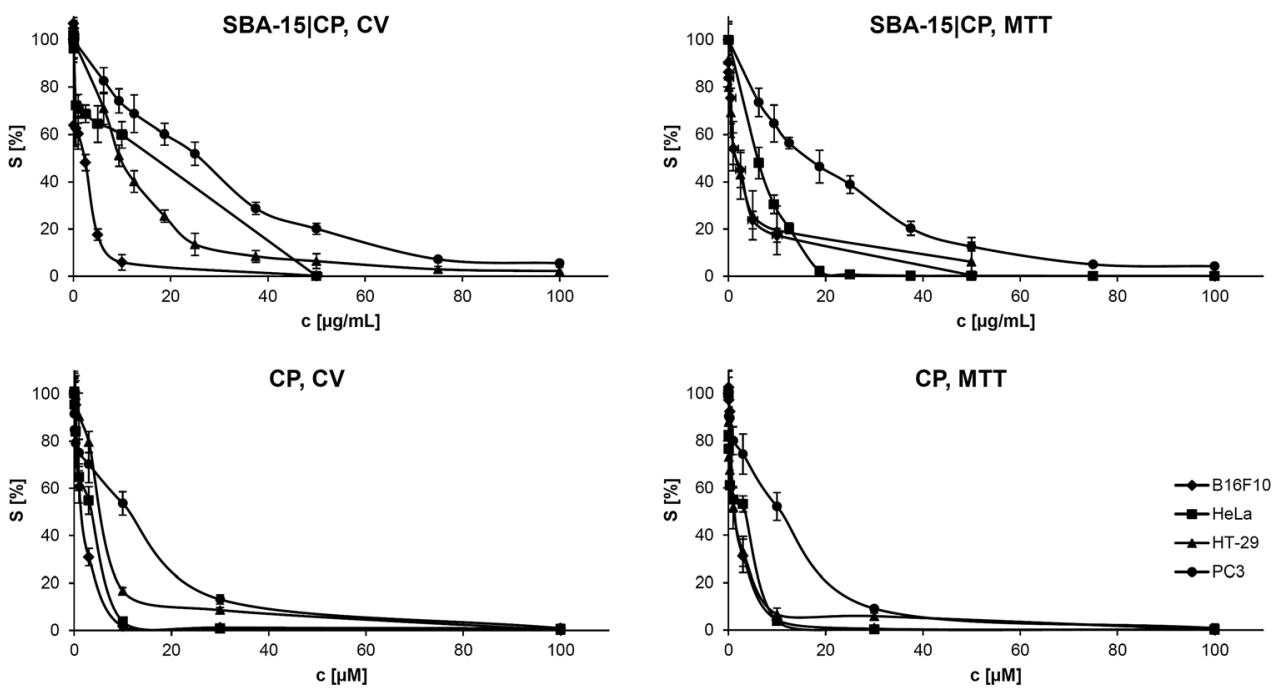

Fig. 4 Survival of tumor cells S (in \%) treated with CP (cisplatin) and SBA-15|CP (48 h).

\subsection{SBA-15|CP enhances ROS formation, abrogates proliferation, induces morphological changes and provokes autophagy in B16F10 cells}

In order to define mechanism of action B16F10 cells were treated with free $\mathrm{CP}$ as well as loaded into SBA-15 and cell cycle analysis was performed (Fig. 5A). Both, CP and SBA-15|CP slightly elevated cell population in sub-G1 phase after $24 \mathrm{~h}$ of treatment. There was almost no alteration on B16F10 cell cycle distribution in treatment with single or double $\mathrm{IC}_{50}$ and $\mathrm{MC}_{50}$ doses. On the other hand, cells treated for $48 \mathrm{~h}$ behaved differently depending on the dose and applied agent.

With higher concentration $\mathrm{CP}$ and SBA-15|CP induced M/G2 phase arrest. However, to some extent increased number of the cells was found in sub-G1 population after 48 than $24 \mathrm{~h}$ of treatment. This was connected with induction of apoptotic cell death.

To verify the apoptotic process annexin V/PI staining was performed (Fig. 5B). Elevated both early and late apoptotic B16F10 cells could be detected for cells treated with respective

Table $2 \quad I C_{50}[\mu \mathrm{M}]$ and $\mathrm{MC}_{50}\left[\mu \mathrm{g} \mathrm{mL} \mathrm{L}^{-1}\right]$ values of $\mathrm{TC}\left(\mathrm{K}_{2}\left[\mathrm{PtCl}_{4}\right]\right), \mathrm{CP}$ (cisplatin), SBA-15, SBA-15|TC and SBA-15|CP determined with CV assay ( $48 \mathrm{~h}$ )

\begin{tabular}{lllll}
\hline $\begin{array}{l}\text { Compound/ } \\
\text { material }\end{array}$ & B16F10 & HeLa & HT-29 & PC3 \\
\hline IC $_{50}[\mu \mathrm{M}]$ & & & & \\
TC & $>100$ & & & \\
CP & $1.49 \pm 0.14$ & $2.29 \pm 0.17$ & $5.03 \pm 0.52$ & $10.66 \pm 0.49$ \\
SBA-15|CP & $0.43 \pm 0.03$ & $3.03 \pm 0.55$ & $3.97 \pm 0.11$ & $9.47 \pm 1.43$
\end{tabular}

$\mathrm{MC}_{50}\left[\mu \mathrm{g} \mathrm{mL}^{-1}\right]$

SBA-15 $>100$

SBA-15|TC $>100$

$\begin{array}{lllll}\mathrm{SBA}-15 \mid \mathrm{CP} & 1.06 \pm 0.08 & 7.50 \pm 1.36 & 9.81 \pm 0.26 & 23.42 \pm 3.55\end{array}$

${ }^{a}$ Recalculated from platinum content (EDX).
$\mathrm{IC}_{50} / \mathrm{MC}_{50}$ doses. Furthermore, with twice higher concentrations boosted early (SBA-15|CP) and late apoptotic (CP) cells were identified. In order to evaluate the biological effect of CPand SBA-15|CP-induced generation of ROS in cancer cells, DHR pretreated B16F10 cells following exposure to CP and SBA-15|CP were investigated (Fig. 5C).

It was found that free CP as well as loaded into SBA-15 (in $\mathrm{IC}_{50} / \mathrm{MC}_{50}$ doses) are elevating production of ROS. This effect was more pronounced by SBA-15|CP in higher than in lower concentration. CFSE-labeled B16F10 cells were cultured with CP and SBA-15|CP for $72 \mathrm{~h}$. Cell proliferation was significantly inhibited by both, CP and SBA-15|CP. Remarkably, B16F10 proliferation was inhibited by more than $60 \%$ before first division by CP and SBA-15|CP.

However, morphological changes have been noticed in the cells treated with SBA-15|CP. Because of that AO staining was performed and cells were visualized under fluorescent microscope (Fig. 6). The cells treated with CP exhibit typical features of apoptosis, in spite of this, rarely some larger cells could be identified. On the other side beside small number of apoptotic

Table $3 \quad \mathrm{IC}_{50}[\mu \mathrm{M}]$ and $\mathrm{MC}_{50}\left[\mu \mathrm{g} \mathrm{mL} \mathrm{mL}^{-1}\right]$ values of TC, CP, SBA-15, SBA$15 \mid T C$ and SBA-15|CP determined with MTT assay (48 h)

\begin{tabular}{|c|c|c|c|c|}
\hline $\begin{array}{l}\text { Compound/ } \\
\text { material }\end{array}$ & B16F10 & HeLa & HT-29 & PC3 \\
\hline \multicolumn{5}{|l|}{$\mathrm{IC}_{50}[\mu \mathrm{M}]$} \\
\hline $\mathrm{TC}$ & $>100$ & & & \\
\hline $\mathrm{CP}$ & $1.29 \pm 0.16$ & $1.32 \pm 0.09$ & $0.92 \pm 0.33$ & $9.26 \pm 3.03$ \\
\hline SBA-15|CP ${ }^{a}$ & $0.72 \pm 0.20$ & $2.54 \pm 0.15$ & $0.62 \pm 0.15$ & $6.32 \pm 0.84$ \\
\hline \multicolumn{5}{|c|}{$\mathrm{MC}_{50}\left[\mu \mathrm{g} \mathrm{mL}^{-1}\right]$} \\
\hline SBA-15 & $>100$ & & & \\
\hline SBA-15|TC & $>100$ & & & \\
\hline SBA-15|CP & $1.79 \pm 0.49$ & $6.28 \pm 0.36$ & $1.53 \pm 0.40$ & $15.63 \pm 2.08$ \\
\hline
\end{tabular}


A

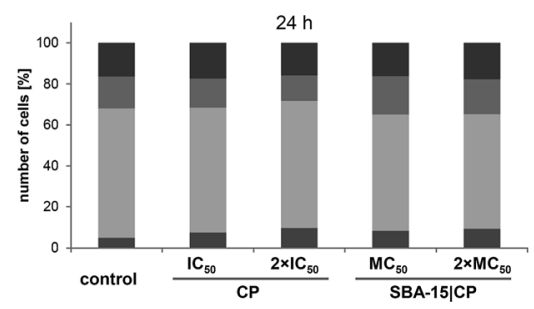

C

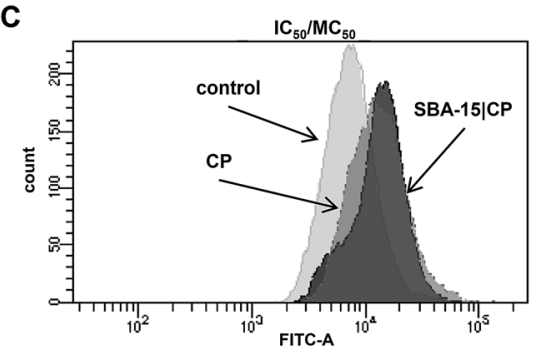

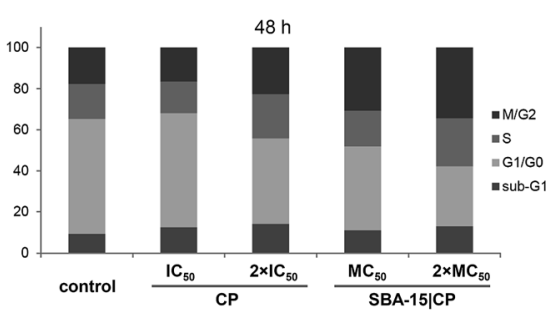

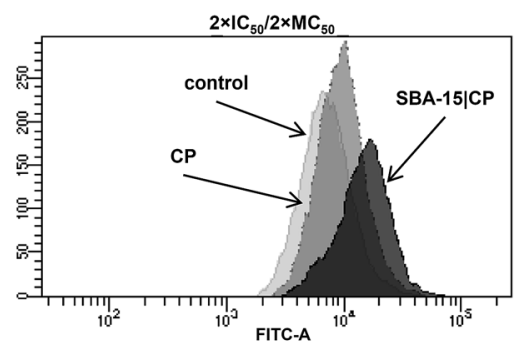

B

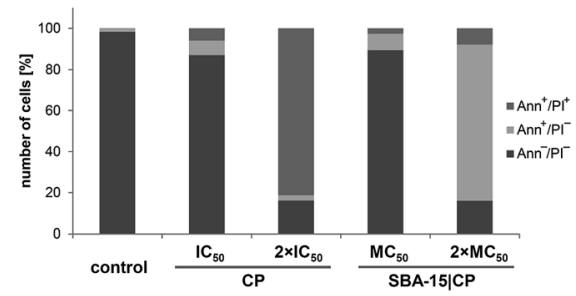

D

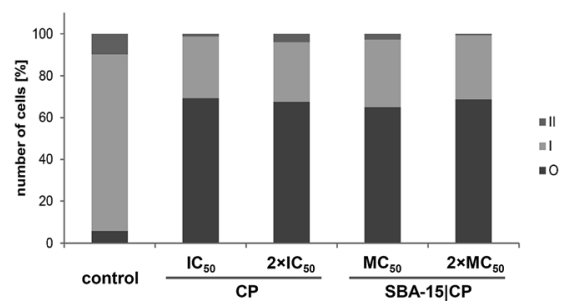

Fig. 5 Effect of CP and SBA-15|CP on B16F10 cells: (A) cell cycle analysis (24 and $48 \mathrm{~h}$ ), (B) induction of apoptosis (48 h), (C) formation of ROS (48 h) and (D) proliferation potential (72 h; O - undivided cells, I - first and II - second cell generations).

cells, B16F10 cells treated with SBA-15|CP exhibited different morphology than untreated cells. Thus, larger cells with flattened morphology were observed. Similar morphological changes were observed on the same tumor cell line when treated with CP polymeric nanocarrier, ${ }^{59}$ but was not further evaluated. Changed morphology of the cells can be correlated to proliferation potential detriment of the cells treated with SBA-15|CP and might point to changes in cellular phenotype of B16F10 cells induced with such MSNs.

Moreover, rare structures suspected as autophagosomes were detected. In order to investigate if $\mathrm{CP}$ alone or SBA-15|CP is inducing autophagy in B16F10 cells flow cytometry analysis was performed (Fig. 6). CP caused slightly elevated autophagy upon treatment with $\mathrm{IC}_{50}$ and $2 \times \mathrm{IC}_{50}$ doses. SBA-15|CP insignificantly increased formation of autophagic vesicles in $\mathrm{MC}_{50}$ dose. Contrary, in higher concentration $\left(2 \times \mathrm{MC}_{50}\right)$ SBA-15|CP drastically enhanced number of autophagic cells was detected.

\subsection{SBA-15|CP induces senescence in B16F10 cells}

Taking all findings together pointing phenotype changes in B16F10 cells, which might be indicative of senescence. Senescent cells accumulate a senescence-associated $\beta$-galactosidase ( $\beta$-gal) activity that distinguishes them from most quiescent cells. ${ }^{60,61}$ The senescence induction could be identified investigating $\beta$-gal activity, which is undetectable in quiescent, immortal or tumor cells. ${ }^{62}$ In order to confirm this assumption, B16F10 cells were treated with CP or SBA-15|CP and analyzed using senescence-associated $\beta$-gal assay (Fig. 7). It became obvious that some CP treated B16F10 cells were enlarged with low $\beta$-gal activity, seen as rare small blue staining of the cells. Such behavior can be correlated with slight autophagy elevation caused by CP. On the contrary, B16F10 cells treated with SBA$15 \mid \mathrm{CP}$ showed clear proofs that such cells undergo senescence. Also here a higher effect is detected for SBA-15|CP, even CP quantity in SBA-15 is in lower amount abundant. Senescent cells regularly down-regulate proliferation and extracellular matrix production. ${ }^{63}$ It is well known that senescent cells often develop a large, flattened morphology. ${ }^{64}$ In some cells ROS production is associated with induction of senescence. ${ }^{65}$

Autophagy and senescence are closely related but not necessarily interdependent responses, nevertheless autophagy can facilitate and accelerate the development of the senescent phenotype. ${ }^{66,67}$ On the other side, senescence may occur without presence of autophagy.$^{68}$ Both could serve to collaterally protect the cell from the toxicity of external stress such as

A
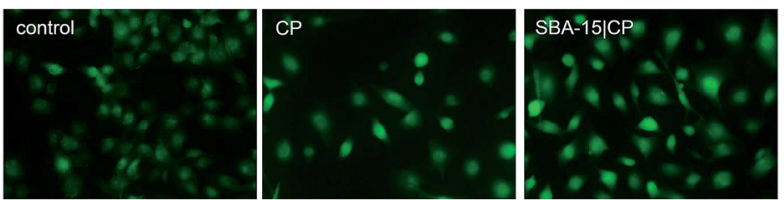

B

control
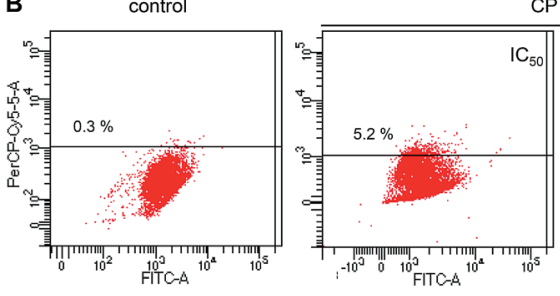

$\mathrm{CP}$

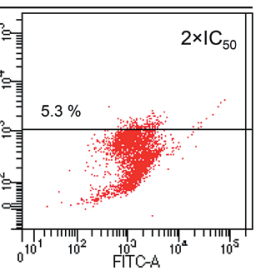

SBA-15|CP

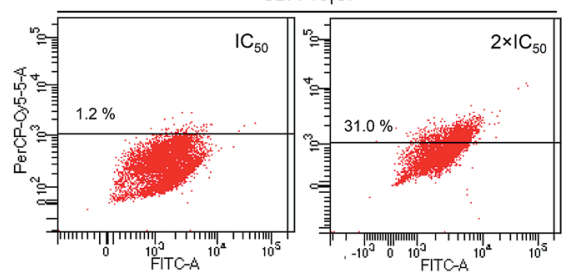

Fig. 6 Morphological changes (A) and autophagy induction (A and $B$ ) in B16F10 cells treated with CP and SBA-15|CP, respectively. 

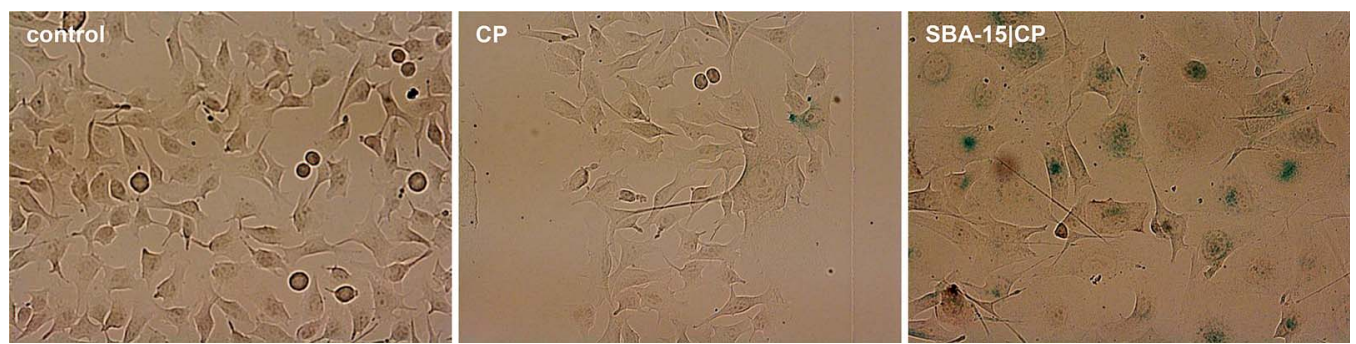

Fig. 7 Cytochemical staining of senescence-associated $\beta$-gal activity in B16F10 cells treated with CP and SBA-15|CP (after 48 h)

chemotherapy. ${ }^{69}$ Stress-induced senescence has been associated with drugs acting on DNA as shown for 5 -fluorouracil. ${ }^{70,71}$ It is well known that $\mathrm{CP}$ also interacts with DNA. ${ }^{12,72}$ Since SBA-15|CP trigger formation of ROS in B16F10 cells the mode of action of this specific MSNs may be connected to stress-induced senescence.

Moreover, in senescent cells autophagy serves as adaptation mechanism to stress. ${ }^{65}$ This can be correlated to the results reported herein, because SBA-15|CP enhances autophagy in B16F10 cells. Significantly, such mode of drug action presents a harmless approach in tumor treatment, since senescent tumor cells can be cleared by immune cells and this may result in efficient tumor regression. ${ }^{73}$

\section{Conclusions}

SBA-15|CP possesses great anticancer potential under in vitro conditions. All four cell lines B16F10, HeLa, HT-29 and PC3 were much more or similarly sensitive to SBA-15|CP as free CP, even if $\mathrm{CP}$ is present in lower concentration. However, there was minimal induction of apoptosis caused by SBA-15|CP. Contrarily, a clear evidence for morphological changes, autophagy induction, prevention of proliferation and ROS formation, whereas the survived cells showed to be in a state of senescence. Even so, the effective controlling of stress is decisive for tumor suppression in which autophagy plays a crucial role. Cells under stress trigger autophagy, which can accelerate senescence or protect cell to allow recovery of normal cell function as tumor suppression mechanisms. Taken together, data reported herein suggest that SBA-15 potentiates and changes targeting activity of $\mathrm{CP}$. This approach presents a safer mode in tumor treatment compared to induced apoptosis alone. The uniqueness of SBA- 15 nanostructured materials derives from their loading suitability with antitumor active compounds. Furthermore, this approach showed potentiation of the mechanism of action of the compounds by SBA- 15 . Therefore, research in this field is intensively proceeding in last few years. ${ }^{74}$

\section{Acknowledgements}

We would like to thank Dr Günter Hempel and Dr Dieter Ströhl (both MLU) for numerous NMR measurements. We greatly appreciate the SEM/TEM/EDX measurements of Wilfried Erfurth, Kornelia Sklarek (both MPI), Dr Filipe Natalio (MLU) and Frank Syrowatka (CMAT) and their contributions towards this work. We would like to express our deep gratitude to Jenny Bienias and Birgit Linder (both MLU) for recording numerous nitrogen adsorption-desorption experiments. Moreover, we would like to thank Prof. Dr S. Ebbinghaus (MLU) for the great opportunity to independently conduct both SAXS and SEM/EDX measurements and the assistance he added to this work. Also, we would like to thanks Prof. Dr S. Mijatović and Prof. Dr D. Maksimović-Ivanić for helpfull discussion.

\section{Notes and references}

1 M.-L. Kung, C.-W. Hsieh, M.-H. Tai, C.-H. Weng, D.-C. Wu, W.-J. Wu, B.-W. Yeh, S.-L. Hsieh, C.-H. Kuo, H.-S. Hung and S. Hsieh, PCCP Phys. Chem. Chem. Phys., 2016, 18, 7124-7131.

2 G. Ciarimboli, Anticancer Res., 2014, 34, 547-550.

3 A. Macciò and C. Madeddu, Expert Opin. Pharmacother., 2013, 14, 1839-1857.

4 B. Ahn, J. Park, K. Singha, H. Park and W. J. Kim, J. Mater. Chem. B, 2013, 1, 2829-2836.

5 A.-M. Florea and D. Büsselberg, Cancers, 2011, 3, 1351-1371.

6 T. C. Johnstone, K. Suntharalingam and S. J. Lippard, Chem. Rev., 2016, 116, 3436-3486.

7 B. Lippert, Coord. Chem. Rev., 1999, 182, 263-295.

8 N. Muhammad and Z. Guo, Curr. Opin. Chem. Biol., 2014, 19, 144-153.

9 C. R. Munteanu and K. Suntharalingam, Dalton Trans., 2015, 44, 13796-13808.

10 I. Kostova, Adv. Anticancer Agents Med. Chem., 2006, 6, 19-32. 11 K. Strohfeldt and M. Tacke, Chem. Soc. Rev., 2008, 37, 11741187.

12 S. Gómez-Ruiz, D. Maksimović-Ivanić, S. Mijatović and G. N. Kaluđerović, Bioinorg. Chem. Appl., 2012, 2012, 140284.

13 C. Mari and G. Gasser, Chimia, 2015, 69, 176-181.

14 H. M. Kieler-Ferguson, J. M. J. Fréchet and F. C. Szoka, Wiley Interdiscip. Rev.: Nanomed. Nanobiotechnol., 2013, 5, 130138.

15 P. Yingchoncharoen, D. S. Kalinowski and D. R. Richardson, Pharmacol. Rev., 2016, 68, 701-787.

16 N. Ž. Knežević and J.-O. Durand, Nanoscale, 2015, 7, 21992209.

17 A. Díaz, M. L. González, R. J. Pérez, A. David, A. Mukherjee, A. Báez, A. Clearfield and J. L. Colón, Nanoscale, 2013, 5, 11456-11463. 
18 Y. Huang, S. P. C. Cole, T. Cai and Y. U. Cai, Oncol. Lett., 2016, 12, 11-15.

19 W. Wu, C. Ye, H. Xiao, X. Sun, W. Qu, X. Li, M. Chen and J. Li, Int. J. Pharm., 2016, 511, 65-72.

20 S. K. Sweeney, Y. Luo, M. A. O'Donnell and J. Assouline, Cancer Nanotechnol., 2016, 7, 3.

21 Z. Yuan, Y. Pan, R. Cheng, L. Sheng, W. Wu, G. Pan, Q. Feng and W. Cui, Nanotechnology, 2016, 27, 245101.

22 K. Braun, A. Pochert, M. Lindén, M. Davoudi, A. Schmidtchen, R. Nordström and M. Malmsten, J. Colloid Interface Sci., 2016, 475, 161-170.

23 H. Jaganathan and B. Godin, Adv. Drug Delivery Rev., 2012, 64, 1800-1819.

24 D. Napierska, L. C. Thomassen, D. Lison, J. A. Martens and P. H. Hoet, Part. Fibre Toxicol., 2010, 7, 39.

25 J.-J. Hu, D. Xiao and X.-Z. Zhang, Small, 2016, 12, 3344-3359.

26 M. Manzano and M. Vallet-Regí, J. Mater. Chem., 2010, 20, 5593-5604.

27 Z. Tao, B. Toms, J. Goodisman and T. Asefa, ACS Nano, 2010, 4, 789-794.

28 Z. Tao, Y. Xie, J. Goodisman and T. Asefa, Langmuir, 2010, 26, 8914-8924.

29 X. Wan, G. Zhang and S. Liu, Macromol. Rapid Commun., 2011, 32, 1082-1089.

30 C. Morelli, P. Maris, D. Sisci, E. Perrotta, E. Brunelli, I. Perrotta, M. L. Panno, A. Tagarelli, C. Versace, M. F. Casula, F. Testa, S. Andò, J. B. Nagy and L. Pasqua, Nanoscale, 2011, 3, 3198-3207.

31 O. Taratula, O. B. Garbuzenko, A. M. Chen and T. Minko, J. Drug Targeting, 2011, 19, 900-914.

32 C.-H. Lin, S.-H. Cheng, W.-N. Liao, P.-R. Wei, P.-J. Sung, C.-F. Weng and C.-H. Lee, Int. J. Pharm., 2012, 429, 138-147.

33 J. Gu, J. Liu, Y. Li, W. Zhao and J. Shi, Langmuir, 2013, 29, 403-410.

34 C. Ceresa, G. Nicolini, R. Rigolio, M. Bossi, L. Pasqua and G. Cavaletti, Curr. Med. Chem., 2013, 20, 2589-2600.

35 Y. Fang, G. Zheng, J. Yang, H. Tang, Y. Zhang, B. Kong, Y. Lv, C. Xu, A. M. Asiri, J. Zi, F. Zhang and D. Zhao, Angew. Chem., Int. Ed. Engl., 2014, 53, 5366-5370.

36 S. Mohapatra, S. R. Rout, R. Narayan and T. K. Maiti, Dalton Trans., 2014, 43, 15841-15850.

37 S. H. van Rijt, D. A. Bölükbas, C. Argyo, S. Datz, M. Lindner, O. Eickelberg, M. Königshoff, T. Bein and S. Meiners, ACS Nano, 2015, 9, 2377-2389.

38 I. Munaweera, Y. Shi, B. Koneru, A. Patel, M. H. Dang, A. J. Di Pasqua and K. J. Balkus, J. Inorg. Biochem., 2015, 153, 23-31.

39 C. de la Torre, L. Mondragón, C. Coll, A. García-Fernández, F. Sancenón, R. Martínez-Máñez, P. Amorós, E. Pérez-Payá and M. Orzáez, Chemistry, 2015, 21, 15506-15510.

40 J. L. Vivero-Escoto and M. Elnagheeb, Nanomaterials, 2015, 54, 2302-2316.

41 W. Xie, L. Hu and X. Yang, Ind. Eng. Chem. Res., 2015, 54, 1505-1512.

42 W. Xie and M. Fan, Chem. Eng. J., 2014, 239, 60-67.

43 D. Perez-Quintanilla, S. Gómez-Ruiz, Ž. Žižak, I. Sierra, S. Prashar, I. del Hierro, M. Fajardo, Z. D. Juranic and G. N. Kaluđerović, Chem.-Eur. J., 2009, 15, 5588-5597.
44 M. Z. Bulatović, D. Maksimović-Ivanić, C. Bensing, S. GómezRuiz, D. Steinborn, H. Schmidt, M. Mojić, A. Korać, I. Golić, D. Perez-Quintanilla, M. Momčilović, S. Mijatović and G. N. Kaluđerović, Angew. Chem., Int. Ed., 2014, 53, 59825987.

45 G. N. Kaluđerović, D. Perez-Quintanilla, Ž. Žižak, Z. D. Juranić and S. Gómez-Ruiz, Dalton Trans., 2010, 39, 2597-2608.

46 A. Garcia-Penas, S. Gómez-Ruiz, D. Perez-Quintanilla, R. Paschke, I. Sierra, S. Prashar, I. del Hierro and G. N. Kaluđerović, J. Inorg. Biochem., 2012, 106, 100-110.

47 G. N. Kaluđerović, D. Perez-Quintanilla, I. Sierra, S. Prashar, I. del Hierro, Z. Zizak, Z. D. Juranic, M. Fajardo and S. Gómez-Ruiz, J. Mater. Chem., 2010, 20, 806-814.

48 D. Zhao, Q. Huo, J. Feng, B. F. Chmelka and G. D. Stucky, J. Am. Chem. Soc., 1998, 120, 6024-6036.

49 D. Srinivas and P. Ratnasamy, Microporous Mesoporous Mater., 2007, 105, 170-180.

50 M. Bulatovic, M. R. Kaluđerović, M. Mojić, B. B. Zmejkovski, E. Hey-Hawkins, M. Vidaković, N. Grdović, G. N. Kaluđerović, S. Mijatović and D. Maksimović-Ivanić, Eur. J. Pharmacol., 2015, 760, 136-144.

51 N. Pantelić, T. P. Stanojković, B. B. Zmejkovski, T. J. Sabo and G. N. Kaluđerović, Eur. J. Med. Chem., 2015, 90, 766-774.

52 G. N. Kaluđerović, V. M. Đinović, Z. D. Juranić, T. P. Stanojković and T. J. Sabo, J. Inorg. Biochem., 2005, 99, 488-496.

53 M. R. Kaluđerović, M. Mojić, S. Gómez-Ruiz, S. Mijatović and D. Maksimović-Ivanić, Adv. Anticancer Agents Med. Chem., 2016, 16, 359-364.

54 G. Ludwig, I. Ranđelović, D. Maksimović-Ivanić, S. Mijatović, M. Z. Bulatović, D. Miljković, M. Korb, H. Lang, D. Steinborn and G. N. Kaluđerović, ChemMedChem, 2014, 9, 1586-1593.

55 F. Arnesano and G. Natile, Coord. Chem. Rev., 2009, 253, 2070-2081.

56 A. R. Forrester, S. J. Garden, R. A. Howie and J. L. Wardell, J. Chem. Soc., Dalton Trans., 1992, 2615-2621.

57 K. Sing, D. Everett, R. Haul, L. Moscou, R. Pierotti, J. Rouquerol and T. Siemieniewska, Pure Appl. Chem., 1985, 57, 603-619.

58 F. Azimov, I. Markova, V. Stefanova and K. Sharipov, J. Chem. Technol. Metall., 2012, 47, 333-340.

59 S. S. Shrikhande, D. S. Jain, R. B. Athawale, A. N. Bajaj, P. Goel, Z. Kamran, Y. Nikam and R. Gude, Saudi Pharm. J., 2015, 23, 341-351.

60 E. White and S. W. Lowe, Genes Dev., 2009, 23, 784-787.

61 J. Campisi, Aging Cell, 2007, 6, 261-263.

62 A. C. Flor, A. P. Doshi and S. J. Kron, Cell Death Discovery, 2016, 2, 16045.

63 V. Krizhanovsky, M. Yon, R. A. Dickins, S. Hearn, J. Simon, C. Miething, H. Yee, L. Zender and S. W. Lowe, Cell, 2008, 134, 657-667.

64 T. Kuilman, C. Michaloglou, W. J. Mooi and D. S. Peeper, Genes Dev., 2010, 24, 2463-2479.

65 C. Focaccetti, A. Bruno, E. Magnani, D. Bartolini, E. Principi, K. Dallaglio, E. O. Bucci, G. Finzi, F. Sessa, D. M. Noonan and A. Albini, PLoS One, 2015, 10, e0115686. 
66 L. Galluzzi, J. M. B.-S. Pedro and G. Kroemer, Trends Cell Biol., 2016, 26, 1-3.

67 R. W. Goehe, X. Di, K. Sharma, M. L. Bristol, S. C. Henderson, K. Valerie, F. Rodier, A. R. Davalos and D. A. Gewirtz, J. Pharmacol. Exp. Ther., 2012, 343, 763-778.

68 D. A. Gewirtz, Autophagy, 2013, 9, 808-812.

69 J. M. Vicencio, L. Galluzzi, N. Tajeddine, C. Ortiz, A. Criollo, E. Tasdemir, E. Morselli, A. Ben Younes, M. C. Maiuri, S. Lavandero and G. Kroemer, Gerontology, 2008, 54, 92-99.
70 D. A. Gewirtz, S. E. Holt and L. W. Elmore, Biochem. Pharmacol., 2008, 76, 947-957.

71 X. Bu, C. Le, F. Jia, X. Guo, L. Zhang, B. Zhang, M. Wu and L. Wei, Cancer Biol. Ther., 2008, 7, 392-396.

72 G. N. Kaluđerović and R. Paschke, Curr. Med. Chem., 2011, 18, 4738-4752.

73 M. Collado and M. Serrano, Nat. Rev. Cancer, 2010, 10, 51-57. 74 J. Siefker, P. Karande and M.-O. Coppens, Expert Opin. Drug Delivery, 2014, 11, 1781-1793. 